\title{
ANALYTICAL STUDY OF BEHAVIOR OF COLD FORMED STEEL SECTIONS WITH AND WITHOUT PERFORATION UNDER COMPRESSIVE LOADING
}

\author{
Majahar. M. Baraskar \\ Department of Applied Mechanics \\ Government College of Engineering, Karad, \\ Maharashtra, India \\ Prof. V. M. Bogar \\ Department of Applied Mechanics \\ Government College of Engineering, Karad, \\ Maharashtra, India
}

\begin{abstract}
Steel is used in construction industry due to its hardness and tensile strength. Cold formed steel is type of steel which is manufactured at lower temperature. Cold form steel became more popular in twentieth century in construction industry due to its high strength to weight ratio and post-buckling strength. The purpose of this study is to study the behavior of cold-formed steel sections of different shapes but of same cross sectional area for compressive loading. Effect of lips within same cross sectional area, effect of perforation and shape stiffener is evaluated on different sections as channel section, $Z$ section and hat section. Eigen value buckling analysis was carried out to on twelve different models to obtain the buckling load and failure pattern. ANSYS WORKBENCH software was used for numerical simulation of sections. I.S. 801:1975 has been taken under consideration wherever required. Based upon the results, optimum section in each of cases as with lips, without lips and perforated amongst all three sections is suggested. Effect of shape stiffeners provided by previous researcher P. Manikandan on solid sections is evaluated to check its suitability with perforated sections.
\end{abstract}

Keywords - CFS, ANSYS Workbench, Perforation, FEM

\section{INTRODUCTION}

Steel is widely being used in the construction industry as well as in other civil engineering applications because of its hardness and high tensile strength. Two types of steels such as Hot-rolled steel and Cold- formed Steel members are commonly used in the practice. Hot-rolled steel members are produced at high temperatures whereas cold-formed steel members are produced at lower temperatures. The use of cold-

\author{
Pranil Shetake \\ Department of Applied Mechanics \\ Government College of Engineering, Karad, \\ Maharashtra, India \\ Dr. Y. M. Ghugal \\ Department of Applied Mechanics \\ Government College of Engineering, Karad, \\ Maharashtra, India
}

formed steel (CFS) sections as the primary load-carrying members in buildings is increasing recently. Now days in India, cold formed steel (CFS) is gaining more popularity due to its wide application in various engineering field due to its high strength to weight ratio. CFS is widely used in car bodies, railway coaching, storage racks as well as in many structural members.

These sections are often accompanied with perforations (holes) for different useful purposes. These holes have been made by pre-punching the sheets. Sometimes they are made by laser cutting tools. Perforations are usually located in the web or flange of CFS members. Holes can alter the buckling behavior of cold form sections and can affect on the ultimate strength of the member. Perforations reduce the ultimate strength of CFS member but at the same time facilitatesor weight reduction, passing conduits of sanitary, electrical, and mechanical works and offers various positions for anchoring with other members. Perforations play their important role for storage rack columns, where various positions for anchoring, bolting and bracing are required. Thus in order to improve its strength various researches have been made. Providing various types stiffeners, we can increase its strength to meet our requirement and still having the advantages of the perforations.

The main objectives of the work are as follows,

$>$ To analyze different cold formed steel sections under compressive loading with and without lips under same cross sectional area.

$>$ To study compressive response of cold formed steel sections with perforation.

$>$ To check the suitability of perforation for cold formed steel sections in compression with the help of shape stiffener. 


\section{International Journal of Engineering Applied Sciences and Technology, 2021 \\ Vol. 5, Issue 9, ISSN No. 2455-2143, Pages 152-161 \\ Published Online January 2021 in IJEAST (http://www.ijeast.com)}

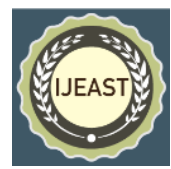

In the previous work, Sadjad Amir Al-Jallad and Haitham Al-Thairy (2016) have investigated effects of web opening on the behavior and failure of cold formed thin walled sections (CFS) subjected to axial compressive load as well as effect of shape of opening considered. From this study, it is found that web opening with ratio ratio of opening width to total section width less than to 0.45 , the increasing of the numbers of web openings results a decreasing of the column axial compressive strength. It is also seen that circular shape of opening shows less reduction compressive strength of column as compare to other shapes. [4]

Boshan Chen et al. (2019) found the effect of edge stiffener in perforated channel section. 26 axial compression tests are performed on unperforated section, perforated section and perforated section with edge stiffners also 49 finite element analysis results are reported on the compression resistance of CFS channel sections with both edge-stiffened and unstiffened web openings. A parametric study was conducted using the finite element model to investigate the effect of opening spacing and column length on compression resistance of channel sections.

It is shown that for the case of a channel section with seven edge-stiffened web openings, the compression resistance was increased by as much as $22 \%$, compared to a plain channel section. For comparison, the same section having unstiffened web openings got a $20 \%$ reduction in compression resistance, compared to a plain channel section.

Chungang Wang et al. (2019) studied influence of perforations on compression behavior of A built-up I-section, a series of pin-ended compression tests and numerical analysis on perforated cold formed steel built-up I-section columns with complex edge stiffeners and web stiffeners were conducted. The test results were found that the web stiffeners could obviously increase the ultimate bearing capacity of the built-up members. Further, a total of 96 parametric analyses were completed to investigate the optimal ratio of the hole depth to web sub-element. This gave rise to an idea of sigma stiffeners with web holes.

Haitham Al-Thairy (2016) conducted experimental survey on two types of members as channel sections and box sections with various opening shapes as square, rectangular and circular and various no. of holes as one, two and three. This parametric study concluded that central hole is best position for single hole while circular shape giving best results.

Muhammad Abed (2016) extended the work of Haitham AlThairy and examined of the behavior of cold-formed thinwalled steel column with opening in ANSYS software for same section sizes. Two groups of steel column were analyzed. The first group has box section while the other has channel section. Materials and geometric nonlinearity were adopted in this study. Furthermore, the effects of column length, location of opening, and stiffener location on behavior of cold formed steel columns were investigated. It was found that, stiffeners have significant effect when they are used at ends of the column rather than they exit around the opening.
Circular opening was found to be best amongst all as in other opening shapes stress concentration is more. Increasing length of the column clearly increases the axial displacement and slightly decreases the load capacity.

Sadjad Amir Al-Jallad and Haitham Al-Thairy (2016) have investigated effects of web opening on the behavior and failure of cold formed thin walled sections (CFS) subjected to axial compressive load as well as effect of shape of opening considered. From this study, it is found that web opening with ratio ratio of opening width to total section width less than to 0.45 , the increasing of the numbers of web openings results a decreasing of the column axial compressive strength. It is also seen that circular shape of opening shows less reduction compressive strength of column as compare to other shapes. holes may modify the local and distortional elastic buckling half-wavelengths, and may also change the critical elastic buckling loads. Found that holes cause mixed distortionallocal mode, hole changes number of half-waves also found that the central hole terminates web local buckling.

Martin Macdonald (2019) et al. studied the effects of perforation position on the compressive load carrying capacity of cold-formed lipped channel sections. Ultimate strength is obtained from numerical, theoretical and experimental investigations for fixed-fixed end condition. The results indicated that current design rules in American Iron and Steel Institute (AISI), British Standards (BS), and European Recommendations are conservative for the load capacity of column members of lipped channel cross-section with perforations subjected to compression loading. Further, the study showed that the reduction in the stiffness of the specimen with perforations on the web was found to be lower than that for the specimen with perforations on the flanges.

G. Ananthi (2016) threw light into the behavior of both lipped and plain channel members with different slenderness ratios comparing with the various international codes of practice for cold-formed sections subjected to compression. The load carrying capacities of plain and lipped channels for seven different slenderness ratios are compared. Load versus axial shortening behaviour for the plain and lipped channels are also presented. It is shown that even a small length of lip increases the axial compressive loading capacity of the member.

P. Manikandan et al. (2017) analyzed four series of cold formed steel channel columns with different types of edge stiffeners under pinned end conditions subjected to axial compression. Test results are simulated with finite element analysis software using ANSYS. The effect of variation of thickness, yield stress and overall slenderness in the strength and behaviour of the section are carried out. Edge stiffeners improve axial loading capacity.

Yerudkar D, Vesmawala G (2017) have studied the post buckling behavior and ultimate strength cold formed steel member under bending. In this work, they analyzed both stiffened element with flange or web intermediate stiffeners and unstiffened. From this study it is found that with flange or web stiffeners, performance of cold formed steel member and 


\section{International Journal of Engineering Applied Sciences and Technology, 2021 \\ Vol. 5, Issue 9, ISSN No. 2455-2143, Pages 152-161 \\ Published Online January 2021 in IJEAST (http://www.ijeast.com)}

resistance to local, distortional and lateral torsional buckling improves and also it is seen that after addition of intermediate stiffeners, the linear buckling loads are reducing in sections having flange width to thickness ratio less than 20. [6]

incorporated in the FE model. Concluded that, strength and stiffness of the member increase with modifying the crosssectional geometries. A specimen with $\Sigma$-type intermediate stiffeners provides better performance compared to all other types of intermediate stiffeners.

From all the literatures examined, it is observed that perforation are required in cold from steel but it comes with it along the disadvantages like decrement in strength of column but at the same time the facilities delivered by perforations can be denied thus many researches tried to improve the strength by many different ways. It is necessary to derive the optimum parameters for this need. One of which is edge stiffened holes which can increase its strength along with perforations. Same is tried to achieve in the work with different cross sections and optimum stiffening arrangement.

\section{METHODOLOGY}

The section sizes were decided first confirming to codal provisions then the material properties were found. Process of providing perforations and stiffeners in addition to that, is also discussed. Detailed procedure of modeling and analysis is stated further.

\section{A. Details Of Different CFS Sections -}

The members of three different cross-sectional shape were selected as channel, zed and hat sections. All the sections were selected satisfying the guidelines of IS 801:1975. The main criteria after following the guidelines of code is to keep the same cross section area of all the sections for both lipped and unlipped sections so that while comparing them and selecting the most suitable section at the same time the economy can also be achieved. Another important provision made in deciding dimensions is that the web is having same depth throughout all the sections. As it is the governing parameter which contributes to the strength of the compression member. Addition of perforation and stiffener is mentioned further in this chapter. Initially all three shapes mentioned earlier were analyzed for unlipped and lipped solid section condition. Then after, perforations were introduced in the section which performs better. In addition to that stiffeners were added in perforated sections at last.
The cross sectional area and length is kept constant to 300 $\mathrm{mm}^{2}$ and $1500 \mathrm{~mm}$ respectively for all sections. Dimensions are as shown in tables below

\section{B. Specifications Of Perforation And Stiffeners}

Same amount of area is reduced for applying perforations in all three sections. Parameters considered while applying perforations were diameter of hole to depth of web ratio, hole spacing to web depth ratio and also keeping odd no. of holes in all the sections. To maintain all of them together was tedious task as hat section has two webs. To follow the same pattern of perforation throughout all the different sections following considerations were made.

Optimum ratios from previous researches were adopted. For determining the size of hole, the range for hole diameter to web depth ratio $(\mathrm{h} / \mathrm{d})$ was adopted as 0.5 to 0.55 and the ratio of hole spacing to depth of web (s/d) was 0.96 constant for all. By fulfilling above requirements the details of perforations are mentioned in table below.

Stiffening was done to perforated sections of channel, $\mathrm{z}$ and hat profiles. In built shape stiffening provide by researcher P. Manikandan for solid sections was evaluated on perforated sections here. Stiffened section profiles and dimensions are shown in figures below.

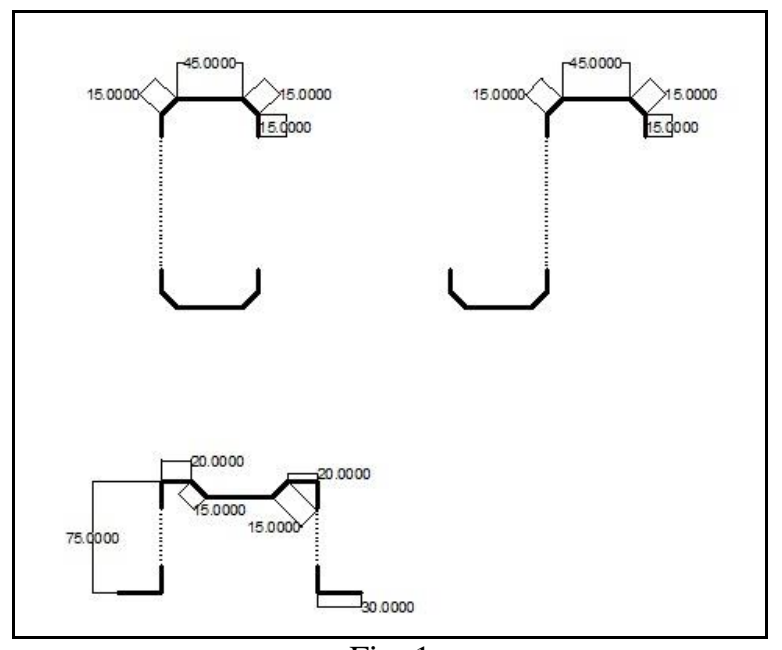

Fig. 1 
International Journal of Engineering Applied Sciences and Technology, 2021

Vol. 5, Issue 9, ISSN No. 2455-2143, Pages 152-161

Published Online January 2021 in IJEAST (http://www.ijeast.com)

Table 1

\begin{tabular}{|c|c|c|c|c|c|}
\hline $\begin{array}{l}\dot{0} \\
\dot{\bar{b}}\end{array}$ & 急 & 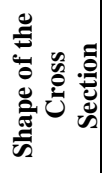 & 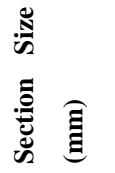 & 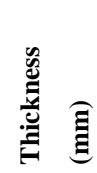 & 总 \\
\hline 1 & CU1500 & & $\begin{array}{l}150 \times 75 \\
\times 75\end{array}$ & 2.5 & 1500 \\
\hline 2 & CL1500 & & $\begin{array}{l}150 \times 60 \\
\times 15\end{array}$ & 2.5 & 1500 \\
\hline 3 & CLP1500 & ए & $\begin{array}{l}150 \times 60 \\
\times 15\end{array}$ & 2.5 & 1500 \\
\hline 4 & CLPS1500 & $\operatorname{sxcos}$ & $\begin{array}{l}\mathrm{x} 120 \mathrm{x} \\
\mathrm{x} 45 \mathrm{x} 15 \\
\mathrm{x} 15\end{array}$ & 2.5 & 1500 \\
\hline 5 & ZU1500 & & $\begin{array}{l}150 \times 75 \\
\times 75\end{array}$ & 2.5 & 1500 \\
\hline 6 & ZL1500 & & $\begin{array}{l}150 \times 60 \\
\times 15\end{array}$ & 2.5 & 1500 \\
\hline 7 & ZLP1500 & \llcorner & $\begin{array}{l}150 \times 60 \\
\times 15\end{array}$ & 2.5 & 1500 \\
\hline 8 & ZLPS1500 & & $\begin{array}{l}120 \times 15 \\
\times \quad 45 \times \\
15 \times 15\end{array}$ & 2.5 & 1500 \\
\hline 9 & HU1500 & & $\begin{array}{lll}75 \times 75 \\
\times \quad 90 \times \\
30\end{array}$ & 2.5 & 1500 \\
\hline 10 & HL1500 & J & $\begin{array}{l}75 \times 75 \\
\times \quad 70 \times \\
25 \times 15\end{array}$ & 2.5 & 1500 \\
\hline 11 & HLP1500 & $\begin{array}{l}\square \\
\sqcup\end{array}$ & $\begin{array}{l}75 \times 75 \\
\times 70 \times \\
25 \times 15\end{array}$ & 2.5 & 1500 \\
\hline 12 & HUPS 1500 & t. & $\begin{array}{l}30 \times 75 \\
\times \quad 20 \times \\
15 \times 20 \times \\
15 \times 20 \\
\times 75 \times 30\end{array}$ & 2.5 & 1500 \\
\hline
\end{tabular}

Labeling For Section Id

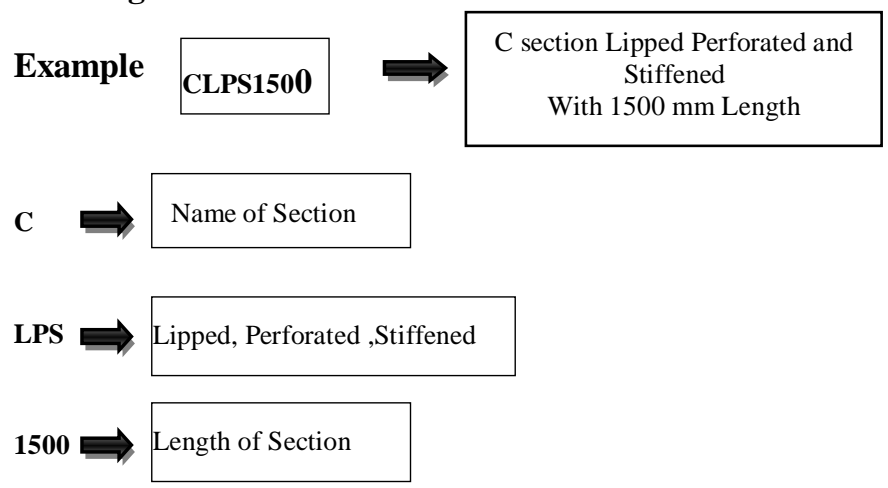

Table 2

\begin{tabular}{|c|c|c|c|}
\hline Sr. No & 1 & 2 & 3 \\
\hline $\begin{array}{l}\text { Section } \\
\text { ID }\end{array}$ & CP1500 & ZP1500 & HP150C \\
\hline $\begin{array}{c}\text { Web Depth } \\
\text { (d) } \\
\text { (mm) }\end{array}$ & 150 & 150 & 75 \\
\hline $\begin{array}{c}\text { Hole } \\
\text { Diameter } \\
\text { (h) } \\
(\mathbf{m m})\end{array}$ & 75 & 75 & 38.55 \\
\hline $\begin{array}{l}\text { Spacing } \\
(\mathbf{c} / \mathrm{c}) \\
(\mathbf{s})\end{array}$ & 145 & 145 & 72.5 \\
\hline h/d & 0.50 & 0.50 & 0.51 \\
\hline$s / d$ & 0.966 & 0.966 & 0.966 \\
\hline $\begin{array}{l}\text { No. Of } \\
\text { Holes }\end{array}$ & 9 & 9 & 34 \\
\hline $\begin{array}{c}\text { Area } \\
\text { Reduced } \\
\left(\mathbf{m m}^{2}\right)\end{array}$ & 39740 & 39740 & 39674 \\
\hline
\end{tabular}




\section{International Journal of Engineering Applied Sciences and Technology, 2021 \\ Vol. 5, Issue 9, ISSN No. 2455-2143, Pages 152-161 \\ Published Online January 2021 in IJEAST (http://www.ijeast.com)}

The material Properties were adopted from previous work done by the researcher P. Manikandan on cold form steel obtained from tension coupon test as yield stress $270 \mathrm{MPa}$, ultimate stress $350 \mathrm{MPa}$, tangent modulus $20000 \mathrm{~N} / \mathrm{mm}^{2}$, modulus of elasticity $2 \times 10^{5} \mathrm{~N} / \mathrm{mm}^{2}$ and Poisson's ratio as 0.3 .

\section{Meshing, Boundary Conditions and Loading}

Meshing was done using $12 \mathrm{~mm}$ element size with multizonal method. Rotation about loading direction is restrained at top and bottom. All the translational degrees of freedom at bottom are restrained while at top all the translational degrees of freedom apart from loading direction are restrained. Axial loading is applied at top selecting faces of the sections in downward direction. . The arbitrary value of load is thus selected as $20,000 \mathrm{~N}$ which will give sufficient amount of deformation and stresses on the sections analyzed in buckling analysis to observe relative performance. Boundary conditions and loadings are shown in figure below.

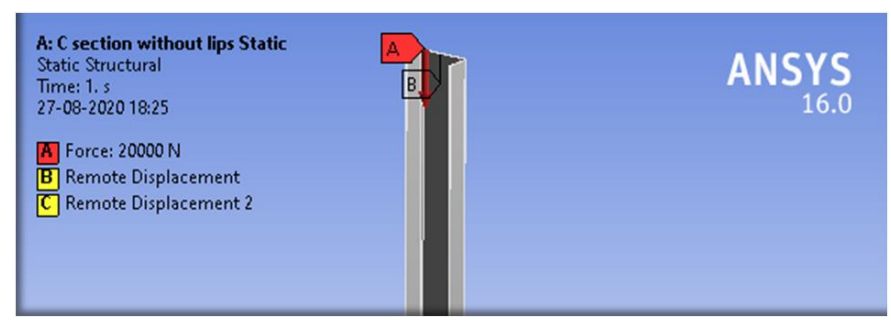

\section{Finite Element Analysis In ANSYS Workbench}

Numerical simulation was done in ANSYS Workbench 2016. Two different analysis systems were used to carry out the analysis work namely "Static Structural System" and "Eigen value Buckling System". Firstly, the analysis was done in Static structural system which was followed by buckling analysis in Eigen value buckling system. Then Eigen value buckling analysis was used to find out the final results.

Total deformation was estimated in static analysis. These results were used for further analysis in Eigen value buckling analysis. All the initial parameters were transferred from the Non-linear static structural system to Eigen value buckling analysis. Thus Load multiplier was obtained. And buckling load was obtained by formula as below,

$$
\mathrm{F}_{\text {BUCKLING }}=\mathrm{F}_{\text {START }}+\lambda_{\mathrm{i}} \cdot \mathrm{F}_{\text {PERTURBATION }}
$$

Where,

$\mathrm{F}_{\text {BUCKLING }}=$ Ultimate buckling load for the structure

$\mathrm{F}_{\mathrm{START}}=$ Total load in static structural analysis

$\lambda=$ Load multiplier

$\mathrm{i}=$ Number of Mode

$\mathrm{F}_{\text {Perturbation }}=$ Load in Eigen value buckling
Sample Calculation

\begin{tabular}{|l|l|l|l|}
\hline $\begin{array}{l}\text { Section } \\
\text { ID }\end{array}$ & $\begin{array}{l}\text { Load } \\
\text { Multiplier }\end{array}$ & $\begin{array}{l}\text { Calculation By } \\
\text { Formula }\end{array}$ & $\begin{array}{l}\text { Buckling } \\
\text { Load (N) }\end{array}$ \\
\hline CU1500 & 2.7598 & $20000+2.7598 \times 20000$ & 75196 \\
\hline
\end{tabular}

\section{RESULTS}

The main objective of the analysis is to study the behaviour different profiles of cold-formed steel sections under compressive loading with and without perforatios with same cross section area. At the end effect of shape stiifeners specified by $\mathrm{P}$. Manikandan in his work was evaluated on perforated sections. Throughtout the study the economy criteria was fullfilled by keeping same cross section area and same length even the lips were provided keeping in mind the same so as to get the relative performance of the mentioned sections. Buckling load is the governing parameter in cold formed materials as compression. Tweleve such analysis were carried out in ANSYS to get the buckling loads and corresponding buckling modes as shown in table 5

\section{Buckling Load}

Buckling load which is the governing parameter for cold formed steel is mentioned in the tables below with their corresponding load multipliers obtained in eigen value buckling analysis. Percentage incriment or decriment in load carrying capacity with respect to previous case in which changes are made to is shown in the rightmost column. Tables are as shown in each case. Results for each of the sections and further comparison for different cases for each of them is shown sequentially with the help of chart and tables as below.

\section{Channel Sections}

Load multilpliers obtained for all the cases of channel sections in Eigen value buckling analysis are shown in the images below detailed. The failure modes can also be observed.

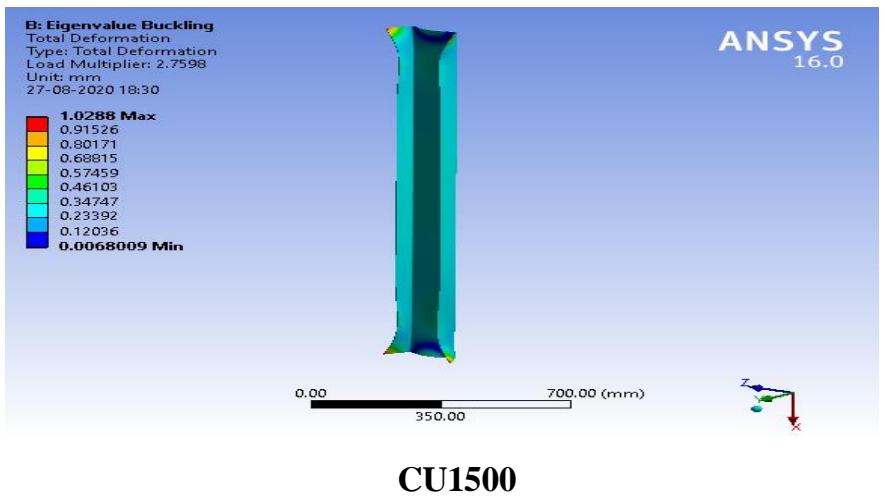

Table 3 


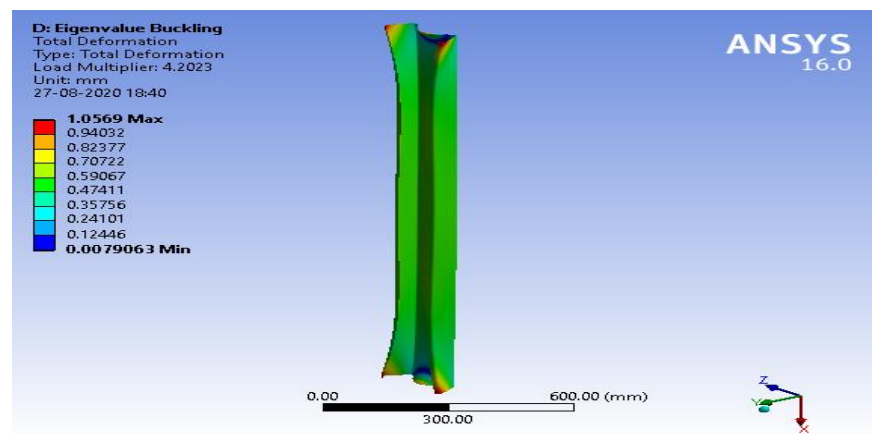

CL1500

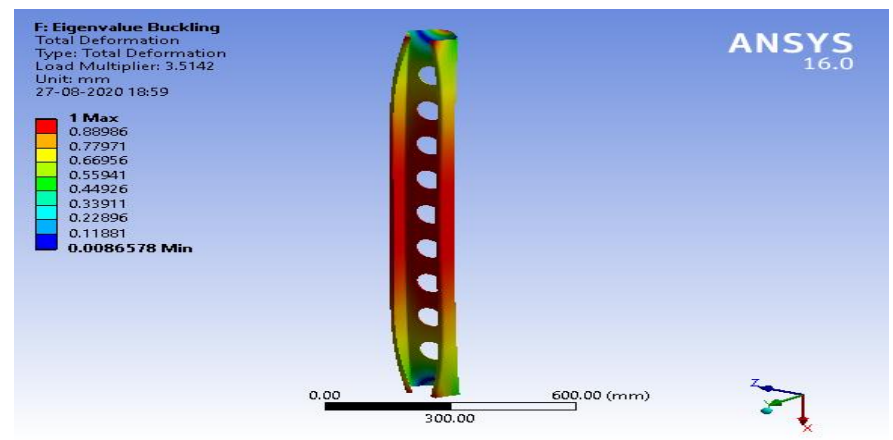

\section{CLP1500}

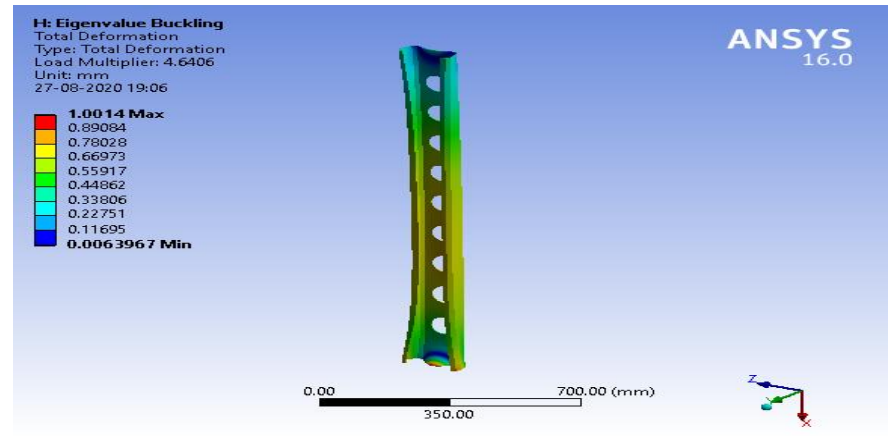

\section{CLPS1500}

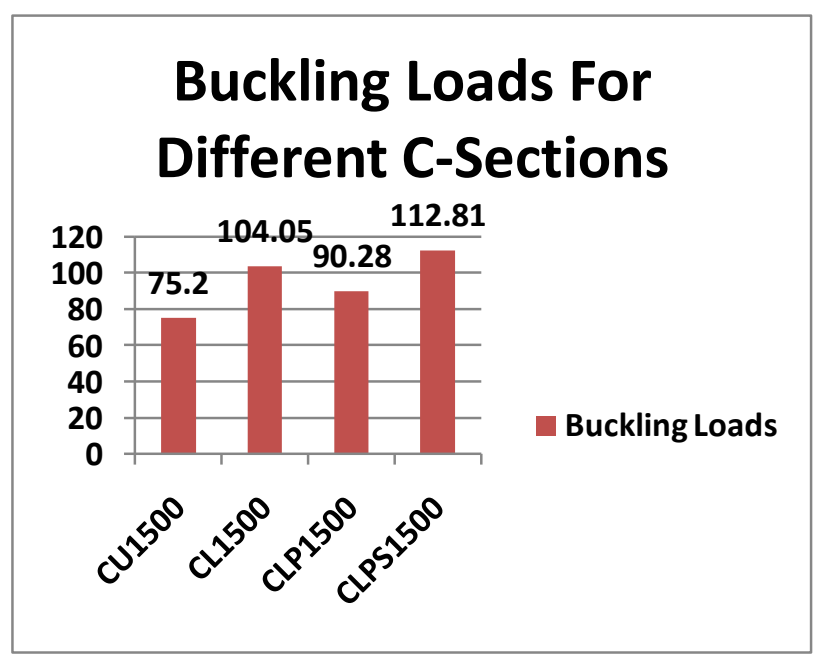

It can be seen that buckling load increased by providing lips keeping the same cross section area. Thus perforations were applied to lipped section further it reduced by the provision of perforations but finally with help of shape stiffeners it was increased beyond all the channel sections.

\section{Z-Sections}

Load multilpliers obtained for all the cases of Z-sections in Eigen value buckling analysis are shown in the images below detailed
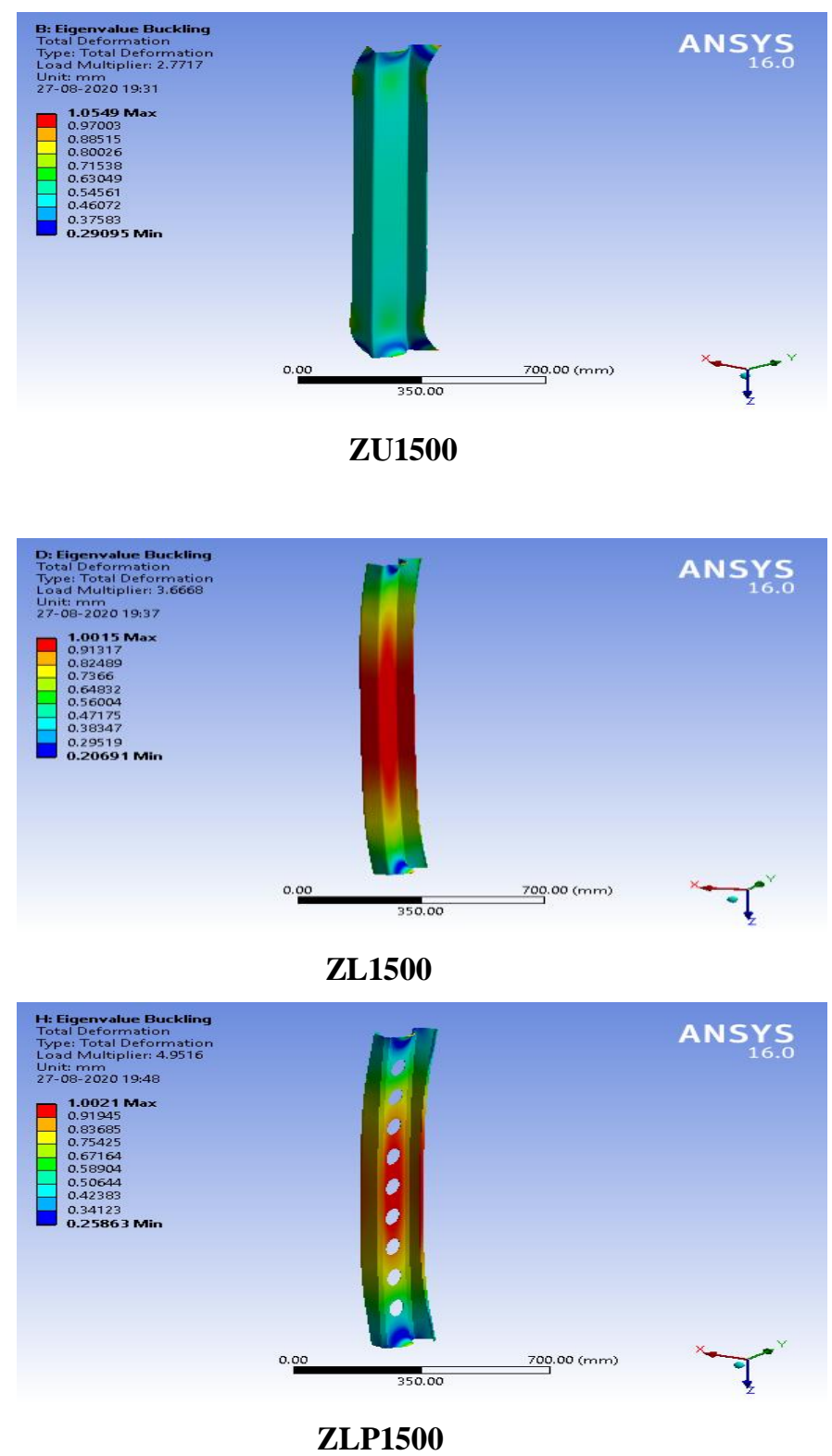


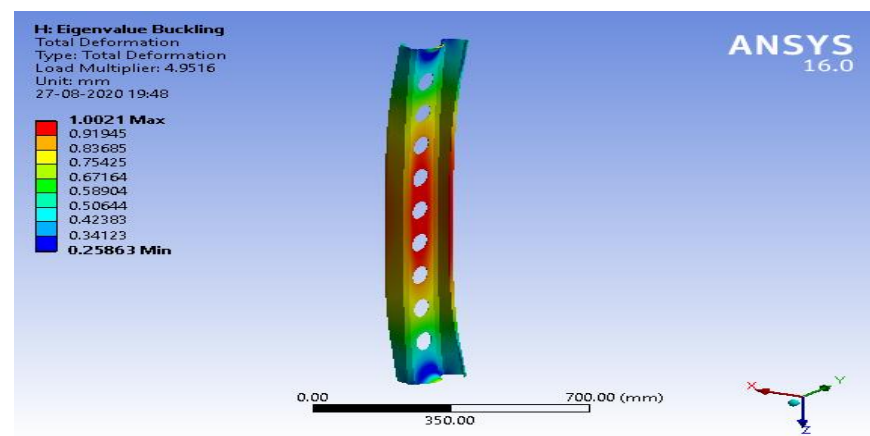

ZLPS1500

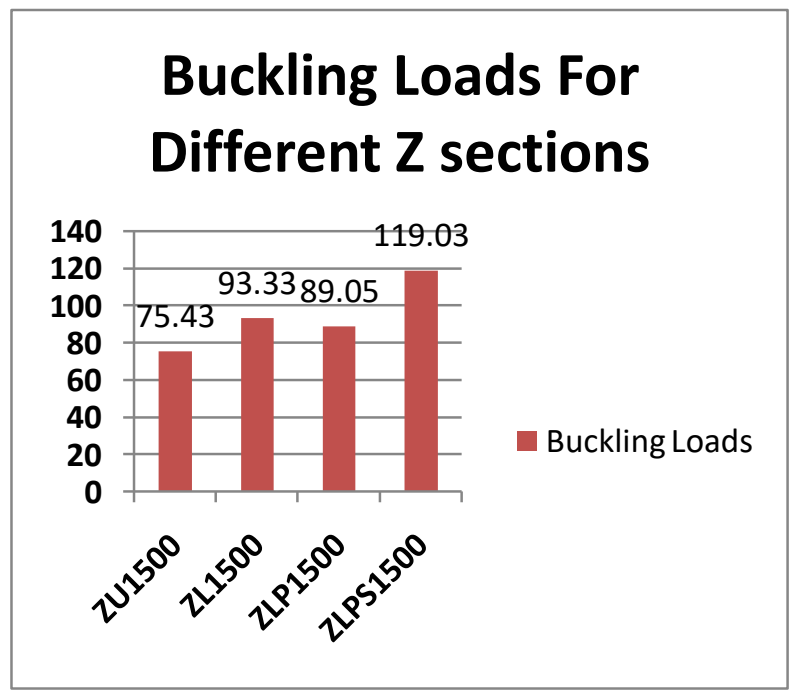

Similar to channel section, buckling load increased by providing lips keeping the same cross section area. Thus perforations were applied to lipped section further it reduced by the provision of perforations but finally with help of shape stiffeners it was increased well beyond all the $\mathrm{z}$ sections.

\section{Hat-Sections}

Load multilpliers obtained for all the cases of Z-sections in Eigen value buckling analysis are shown in the images below detailed

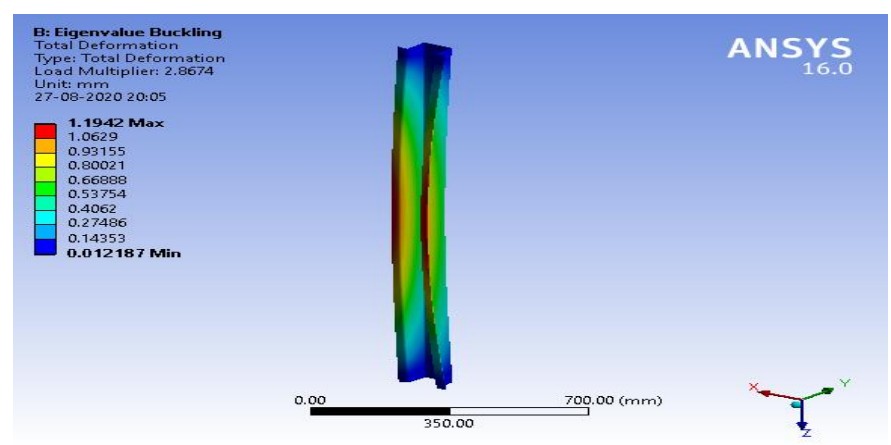

HU1500

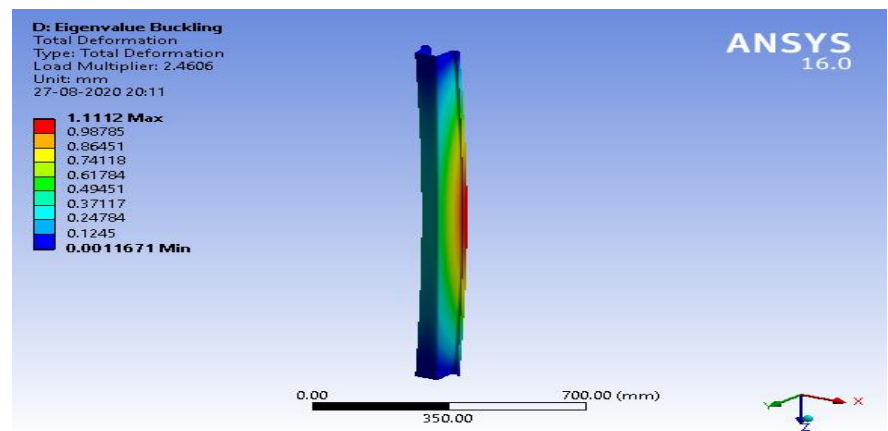

HL1500

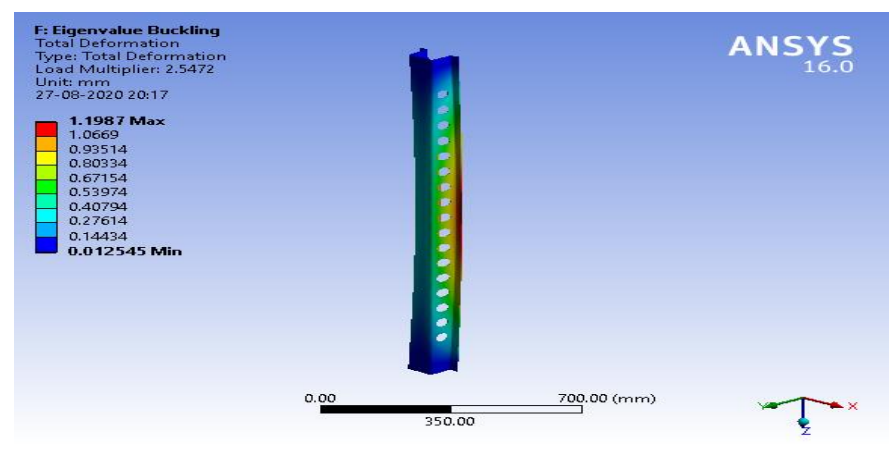

HUP1500

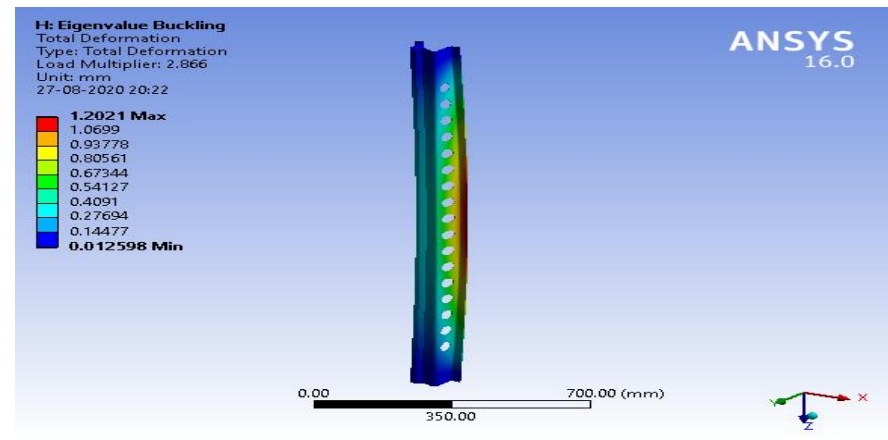

HUPS1500

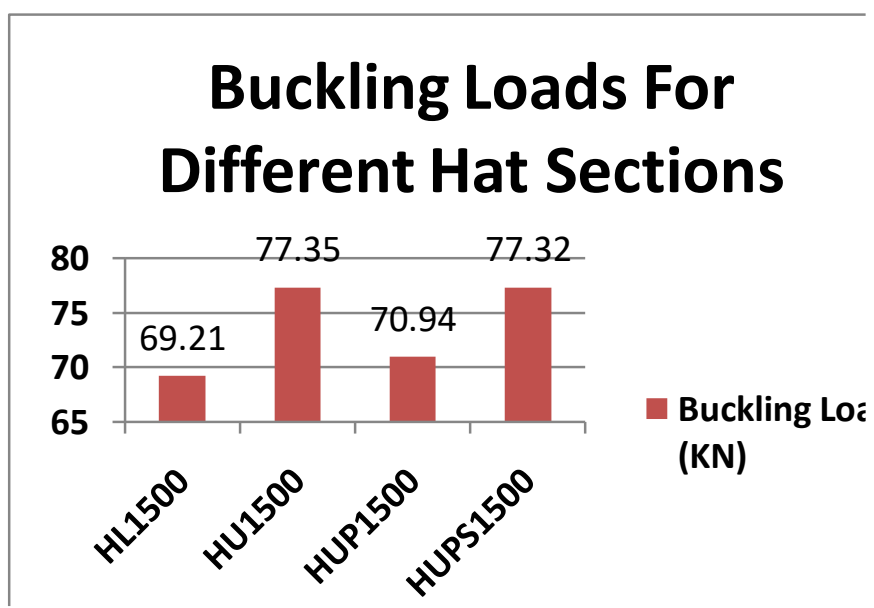




\section{International Journal of Engineering Applied Sciences and Technology, 2021 \\ Vol. 5, Issue 9, ISSN No. 2455-2143, Pages 152-161 \\ Published Online January 2021 in IJEAST (http://www.ijeast.com)}

Contrary to channel and $\mathrm{z}$ sections here buckling load decreased by providing lips keeping the same cross section area. It may be due different structure of hat section having two webs. Thus perforations were applied to unlipped hat sections further it reduced by the provision of perforations but finally with help of shape stiffeners it was increased. However incriment was not up to the mark.

\section{Comparative Study of All Three Sections in All Cases}

\section{a) Unlipped Sections}

Hat section without lip has more buckling load capacity that those of $\mathrm{z}$ and channel sections who showed almost same capacity. This may be because of its shape and two webs.
The sections which performed better between with lips and without lips were selected for application of perforation. Thus perforations were provided in the lipped channel and $\mathrm{z}$ section while in case of hat section perforations were provided in unlipped hat section.

\section{c) Perforated Sections}

Area of perforations on all three sections was kept same to observe their the relative performance. It can be seen that channel section and $\mathrm{z}$ section showed almost same buckling load while hat section showed comparatively less buckling load.

\begin{tabular}{|c|c|c|c|c|c|}
\hline \multicolumn{6}{|c|}{ Table 4 : Results } \\
\hline $\begin{array}{l}\text { Sr. } \\
\text { No. }\end{array}$ & Section ID & $\begin{array}{c}\text { Load } \\
\text { Multiplier }\end{array}$ & $\begin{array}{l}\text { Buckling } \\
\text { Load }(K N)\end{array}$ & $\begin{array}{l}\text { Percentage } \\
\text { Change } \\
\qquad \%)\end{array}$ & Failure Modes \\
\hline 1 & CU1500 & 2.7598 & 75.20 & - & Distortional Buckling \\
\hline 2 & CL1500 & 4.2023 & 104.05 & +38.37 & Distortional Buckling + Flexural buckling \\
\hline 3 & CLP1500 & 3.5142 & 90.28 & -13.22 & Distortional Buckling + Flexural buckling \\
\hline 4 & CLPS1500 & 4.6406 & 112.81 & +24.95 & Flexural buckling \\
\hline 5 & ZU1500 & 2.7717 & 75.43 & - & Distortional Buckling \\
\hline 6 & ZL1500 & 3.6668 & 93.33 & +23.73 & Distortional Buckling + Flexural buckling \\
\hline 7 & ZLP1500 & 3.4524 & 89.05 & -4.59 & Distortional Buckling + Flexural buckling \\
\hline 8 & ZLPS1500 & 4.9516 & 119.03 & +33.67 & Distortional Buckling + Flexural buckling \\
\hline 9 & HU1500 & 2.8674 & 77.35 & - & Local buckling + Flexural Buckling \\
\hline 10 & HL1500 & 2.4606 & 69.21 & -10.52 & Local buckling + Flexural Buckling \\
\hline 11 & HUP1500 & 2.5472 & 70.94 & -8.29 & Local buckling + Flexural Buckling \\
\hline 12 & HUPS1500 & 2.8660 & 77.32 & +9.00 & Flexural buckling \\
\hline
\end{tabular}

\section{b) Lipped Sections}

It can be observed that Channel section with lip showed more buckling load followed by $\mathrm{z}$ and hat respectively.

\section{d) Perforated And Stiffened Sections}

Finally shape stiffeners were introduced in all the perforated sections in order to achieve the strength gain. It can easily be 


\section{International Journal of Engineering Applied Sciences and Technology, 2021 \\ Vol. 5, Issue 9, ISSN No. 2455-2143, Pages 152-161 \\ Published Online January 2021 in IJEAST (http://www.ijeast.com)}

observed that the newly invented stiffened perforated $\mathrm{z}$ section has buckling strength better than the remaining two.
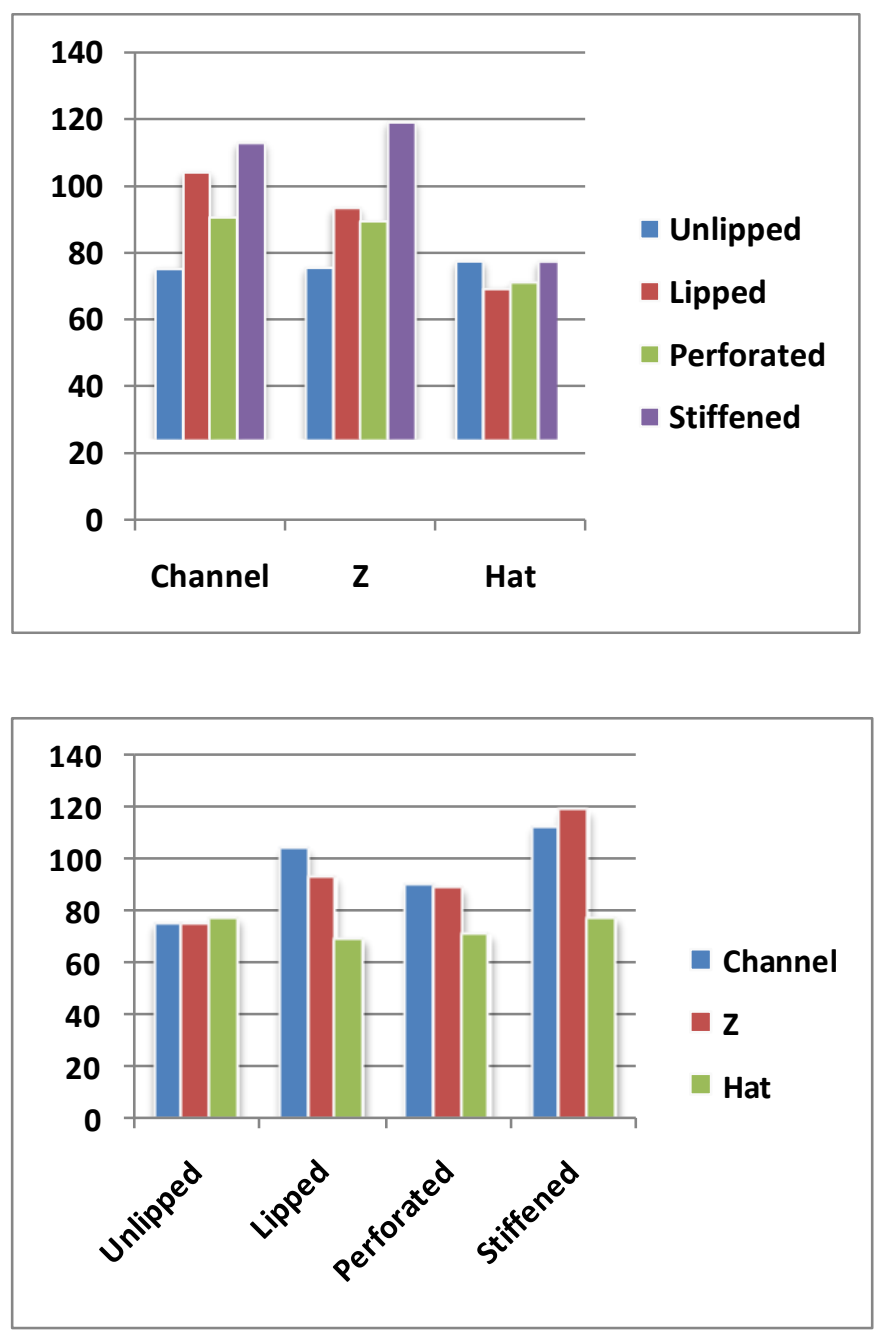

e) Effect Of Lips Within Same Cross Sectional Area On Buckling Load

Lips are generally provided on unlipped sections as an extra part but here in this study they are provided without adding extra dimension keeping same cross section area.

\section{CONCLUSION}

Eigen value buckling analysis was performed to get the buckling capacity of column in compressive loading. Throughout the study area of cross sections was kept constant even lips were added in the same cross section area. Same area of perforation was reduced from all the perforated sections. In general stiffeners add extra material to it while shape stiffeners used in this study don't add extra extra material. In built shape stiffeners studied by previous researcher P. Manikandan on solid channel sections were evaluated on all the perforated sections at the end. Based on all above following conclusions are drawn.

- Adding lips within same cross sectional area to channel and $\mathrm{z}$ sections increased their buckling load capacity by almost $38 \%$ and $23 \%$ while contrary to this it decreased for hat section by $10.52 \%$ which may be due to its different property of cross section having two webs. Channel section performed better amongst all sections with lips

- Buckling strength reduced due to perforation was found to be maximum in channel section with $13 \%$ decrement and $8 \%$ for hat section while it was optimum for $\mathrm{z}$ sections with $4 \%$ decrement. It can be concluded that $\mathrm{z}$ section performed better with perforations amongst all sections.

- After adding in built shape edge stiffeners to perforated sections, there was significant improvement in channel and $\mathrm{Z}$ sections as $24 \%$ and $33 \%$ respectively which was beyond their solid sections strengths while it didn't show any significant change for hat sections which was only $9 \%$ leaving $\mathrm{Z}$ section for the optimum performing section amongst all with perforations and in built shape stiffeners.

- Overall, Channel and Z sections showed similar performance to an extent although $\mathrm{z}$ was best.

- Many of the sections within channel and Z, failed by at least one of the failure as distortional failure while hat sections didn't at all show distortional failure.

- It can finally be concluded that, providing perforation decreases the strength of compressive cold formed steel member however when shape stiffeners are used along with it the strength increases beyond solid section strength with provision of advantages of holes along with strength as that of solid sections.

\section{REFERENCE}

[1] Manikandan P., Pradeep T. (2018), "Effective Cross Section Of Cold Formed Steel Column Under Axial Compression", Journal of The Institution of Engineers (India): Series A, pp. 245-255,

[2] Chena B., Roya K., Uzzamanb A. (2019), Rafterya G.,Nashb D. ,Cliftona G., Pouladia P., Lim J., "Effects Of Edge-Stiffened Web Openings On The Behaviour Of Cold-Formed Steel Channel Sections Under Compression", Thin-Walled Structures 144, pp. 1-21

[3] Wang C.,Guo Q.,Zhang Z., Guo Y.(2019), "Experimental And Numerical Investigation Of Perforated Cold-Formed Steel Built-Up I-Section Columns With Web Stiffeners And Complex Edge Stiffeners", Advances in Structural Engineering, pp. 1-17 
[4] Haitham Al-Thairy (2016), "Effect Of Web Opening On The Axial Load Capacity Of Steel Columns With Cold Formed Thin Walled Section (CFS)", Kufa Journal of Engineering Vol. 7, No. 3, pp. 13-26

[5] Muhammad Attiya A.(2016), "A Finite Element Study of the Behavior of Cold Formed Thin Opened Walled Steel Column", International Journal Of Scientific \& Engineering Research, Volume 7, Issue 7, pp. 1043-1053

[6] Moen C.,,Schafer B.(2008), "Experiments On ColdFormed Steel Columns With Holes ", Thin-Walled Structures 46, pp. 1164-1182

[7] Macdonald M.,Kulatunga M. and Kotełko M.(2019), "The Effects Of Compression Loading On Perforated ColdFormed Thin-Walled Steel Structural Members Of Lipped-Channel Cross-section", AIP Conference Proceedings, Vol. 2060, Issue 1, pp. 1-10

[8] Beulah G.and Ananthi G.(2016), "Performance of Plain and Lipped Cold-Formed Channel Sections in Axial Compression", Scopus Compendex and Geobase Elsevier, Geo-Ref Information Services-USA, List B of Scientific Journals, International Journal of Earth Sciences and Engineering, Poland, Volume 09, pp. 885-887

[9] Manikandan P., Aruna G, Balaji S.,Sukumar S.and Sivakumar M.(2017), "Evaluation On Effectiveness Of Cold-Formed Steel Column With Various Types Of Edge Stiffener", Arab Journal Of Science Engineering, 42, pp. 4157-4168

[10] Manikandan P, Sukumar S.and Kannan K.(2018), "Distortional Buckling Behavior Of Intermediate Cold Formed Steel Lipped Channel Section With Various Web Stiffeners Under Compression", International Journal of Advanced Structural Engineering, Vol. 10, pp. 189-198

[11] "Designers, Specifiers And Buyers Handbook For Perforated Metals", A publication of the Industrial Perforators Association, 1993

[12] IS: 811, "Specification for Cold-formed Light Gauge Structural Steel Sections", Bureau of Indian Standards, 1987

[13] IS: 801, "Code of Practice for Use of Cold formed Light Gauge Steel Structural Members in General Building Construction", Bureau of Indian Standards, 1975. 